\title{
MANAJEMEN SISTEM INFORMASI DI PERPUSTAKAAN SMK NEGERI 3 MALANG
}

\author{
Hanafi Almas \\ hanafialmas23@gmail.com \\ Program Studi SI Ilmu Perpustakaan, Jurusan Sastra Indonesia, Fakultas Sastra \\ Universitas Negeri Malang
}

\begin{abstract}
Abstrak: Penyelenggaraan perpustakaan disetiap instansi baik lembaga pendidikan maupun non-pendidikan berperann sebagai pusat dan sumber segala informasi. Saat ini banyak jenis-jenis perpustakaan, salah satunya perpustakaan sekolah, perpustakaan yang berada di lingkungan sekolah yang tentu memiliki peran sebagai penunjang kegiatan belajar mengajar di sekolah. Sejalan dengan perkembangan teknologi informasi dan ilmu pengetahuan, perpustakaan tentu juga harus mengikuti perubahan tersebut guna memberikan pelayanan yang lebih baik kepada pengguna perpustakaan. Namun, tersedianya perlengkapan teknologi informasi di perpustakaan saja tidak cukup jika tidak kelola dengan manajemen sistem informasi. Perpustakaan SMK Negeri 3 Malang menerapkan sistem automasi perpustakaan dalam memberikan pelayanan di perpustakaan. Hasil temuan dari kegiatan PKL (Praktik Kerja Lapangan) dan observasi yang dilakukan oleh penulis melihat fakta di lapangan terkait penerapan sistem automasi di Perpustakaan SMK Negeri 3 Malang tidak sepenuhnya berperan dalam kegiatan operasional di perpustakaan tersebut. Mengacu pada teori manajemen sistem informasi di perpustakaan dan observasi oleh penulis akan menjabarkan analisis terkait penerapan sistem informasi di Perpustakaan SMK Negeri 3 Malang.
\end{abstract}

Kata Kunci: Manajemen sistem informasi, sistem informasi, perpustakaan sekolah

\begin{abstract}
Implementation of each library agencies both educational institutions and non-education berperann as the center and source of all information. Today many types of libraries, one school library, libraries are a school which would have a role as supporting teaching and learning in schools. In line with the development of information technology and science, the library had to follow these changes in order to provide better service to the users of the library. However, the availability of information technology equipment in the library alone is not enough if it is not managed by the management information systems. SMK Negeri 3 Malang implementing library automation system to provide services at the library. The findings of the activities of street vendors (Field Work Practice) and the observations made by the
\end{abstract}


authors look at the facts on the ground related to the implementation of the automation system at the Library of SMK Negeri 3 Malang not fully play a role in operational activities in the library. Referring to the theory of information management systems in libraries and observations by the authors will describe the related analysis application of information systems at the Library of SMK Negeri 3 Malang.

Key Words: Management information systems, information systems, school libraries

\section{PENDAHULUAN}

Kemajuan teknologi dan informasi pada era globalisasi saat ini berkembang dengan pesat. Hal tersebut berdampak pada tersedianya perangkat serta media untuk memudahkan dalam mengakses informasi dan ilmu pengetahuan. Informasi dan ilmu pengetahuan yang sebagian dapat diakses melalui media internet tidak seluruhnya dapat digunakan oleh pengguna karena tidak mencantumkan sumber yang jelas. Disinilah peran dari perpustakaan untuk menyimpan, mengolah, mengorganisir, informasi dan ilmu pengetahuan sebelum disajikan kepada pengguna perpustakaan. Menurut Lasa HS (2009:20) perpustakaan merupakan sistem informasi yang didalamnya terdapat aktivitas pengumpulan, pengolahan, pengawetan, pelestarian, penyajian, dan penyebar informasi. Saat ini perpustakaan sebagai institusi pengelola informasi merupakan salah satu bidang penerapan teknologi informasi yang berkembang pesat. Sejalan dengan perkembangan teknologi dan informasi saat ini, perpustakaan juga dituntut untuk dapat mengembangkan pelayanan baik dari sarana dan prasarana, dengan memanfaatkan perkembangan teknologi. Dukungan dari perkembangan teknologi informasi tersebut, diharapkan perpustakaan dapat memuhi dan memudahkan setiap pengguna untuk memenuhi kebutuhan informasi.

Perpustakaan SMK Negeri 3 Malang sebagai pusat sumber informasi dan ilmu pengetahuan, berperan penting dalam menunjang proses kegiatan belajar mengajar di SMK Negeri 3 Malang. Dalam penggunaan teknologi informasi, Perpustakaan SMK Negeri 3 Malang menggunakan aplikasi automasi. Penggunaan sistem automasi tersebut diharapkan dapat memberikan pelayanan yang maksimal kepada pengguna perpustakaan. Selain untuk memberikan 
pelayanan yang maksimal, jika dilihat dari koleksi yang tersedia di Perpustakaan SMK Negeri 3 Malang dengan jumlah mencapai lebih dari 48.000 eksemplar. Dengan jumlah bahan pustaka yang cukup banyak tentu diperlukan manajemen sistem informasi perpustakaan agar dapat terorgranisir dengan baik, dan salah satu cara dengan penggunaan aplikasi automasi perpustakaan.

Penggunaan aplikasi automasi di Perpustakaan SMK Negeri 3 Malang diharapkan dapat menunjang kegiatan operasional di perpustakaan. Hasil yang didapatkan oleh penulis dari kegiatan PKL (Praktik Kerja Lapangan) di Perpustakaan SMK Negeri 3 Malang, penggunaan aplikasi automasi tersebut tidak sepenuhnya digunakan dalam kegiatan operasional di Perpustakaan SMK Negeri 3 Malang. Pada artikel ini, penulis akan membahas terkait analisis manajemen sistem informasi di Perpustakaan SMK Negeri 3 Malang.

\section{PEMBAHASAN}

\section{LANDASAN TEORI}

\section{Pengertian Perpustakaan Sekolah}

Perpustakaan sekolah adalah perpustakaan yang berada dalam lingkungan sekolah. Penyelenggaraan perpustakaan sekolah sebagai jantung dari segala ilmu pengetahuan dan informasi disekolah sangat berperan penting untuk menunjang kegiatan belajar mengajar di sekolah. Menurut Undang-undang Republik Indonesia Nomor 43 tahun 2007 Tentang Perpustakaan, menyatakan : Perpustakaan adalah institusi pengelola koleksi karya tulis, karya cetak, dan/atau karya rekam secara profesional dengan sistem yang baku guna memenuhi kebutuhan pendidikan, penelitian, pelestarian, informasi, dan rekreasi para pemustaka.

Perpustakaan dapat pula diartikan sebagai tempat kumpulan buku-buku atau tempat buku yang dihimpun dan diorganisasikan sebagai media belajar siswa Darmono (2001:1). Berdasarkan pendapat diatas dapat disimpulkan bahwa, perpustakaan sekolah adalah perpustakaan yang berada dalam lingkungan sekolah sebagai pusat sumber informasi dan ilmu pengetahuan bagi seluruh warga sekolah. 


\section{Tujuan Perpustakaan Sekolah}

Sebagai sumber dari informasi dan ilmu pengetahuan, perpustakaan sekolah memegang peran penting dalam penyebarluasan ilmu pengetahuan di lembaga induknya yaitu sekolah. Perpustakaan sekolah tidak hanya sebatas ruangan untuk menyimpan bahan-bahan pustaka saja, tetapi dengan adanya penyelenggaraan perpustakaan sekolah diharapkan dapat membantu siswa dan guru menyelesaikan tugas-tugas dalam proses belajar mengajar. Maka dari itu bahan pustaka yang disediakan oleh perpustakaan harus sesuai dengan kurikulum sekolah dan kebutuhan siswa dan guru di sekolah. Menurut Darmono (2001:5) "Perpustakaan sekolah tampak bermanfaat apabila benar-benar memperlancar pencapaian tujuan proses belajar mengajar disekolah". Jika perpustakaan dapat mendukung segala proses belajar mengajar disekolah maka tujuan dari perpustakaan sekolah tersebut telah tercapai dan keberhasilan sebuah perpustakaan sekolah akan sangat berpengaruh terhadap kemajuan sekolah itu sendiri.

\section{Penerapan Teknologi Informasi di Perpustakaan}

Menurut Bustari (2007:80) penerapan teknologi informasi di perpustakaan dapat difungsikan dalam berbagai bentuk, antara lain :

1. Penerapan teknologi informasi digunakan sebagai sistem informasi manajemen perpustakaan. Bidang pekerjaan yang dapat diintegrasikan dengan sistem informasi manajemen perpustakaanadalah pengadaan, inventarisasi, katalogisasi, sirkulasi bahan pustaka, pengelolaan anggota,data statistik dan sebagainya. Fungsi ini sering diistilahkan sebagai bentuk otomasiperpustakaan.

2. Penerapan teknologi informasi sebagai sarana untuk menyimpan, mendapatkan danmenyebarluaskan informasi ilmu pengetahuan dalam format digital. Bentuk penerapan teknologi informasi ini sering dikenal dengan perpustakaan digital.

\section{Automasi Perpustakaan}

Automasi perpustakaan (library automation system) adalah seperangkat aplikasi komputer untuk kegiatan di perpustakaan yang terutama bercirikan 
penggunaan pangkalan data ukuran besar, dengan kandungan cantuman tekstual yang dominan, dan dengan fasilitas utama dalam hal menyimpan, menemukan, dan menyajikan informasi (Pendit, 2009:154). Dengan adanya teknologi informasi maka perpustakaan dapat meningkatkan pelayanan dan dalam proses pemenuhan kebutuhan informasi baik sebagai pengguna maupun penyedia informasi akan berjalan dengan lancar.

\section{METODE ANALISIS}

Metode analisis dengan metode penelitian deskriptif eksploratif, yakni melakukan analisis hanya sampai taraf deskripsi dan menyajikan data secara sistematik agar lebih mudah dipahami dan disimpulkan. Penelitian deskriptif eksploratif juga berujuan untuk menggambarkan keadaan suatu fenomena, tidak dimaksudkan untuk menguji hipotesis tertentu tapi hanya menggambarkan apa adanya suatu variabel, gejala atau keadaan

Metode analisis pada artikel ini, dengan mengacu pada teori yang dipaparkan dalam Pengantar Konsep Dasar Manajemen Sistem Informasi dan Teknologi Informasi dengan artikel terkait Matriks Strategi Sistem Informasi. Adapun pendekatan aspek manajemen sistem informasi di perpustakaan pada artikel tersebut dipaparkan yakni seberapa besar ketergantungan perusahaan atau organisasi terhadap keberadaan teknologi informasi terkait produk jasa yang disediakan serta untuk meningkatkan keunggulan kompetitif. Sebuah organisasi juga harus memetakan setiap aplikasi atau infrastruktur yang dimilikinya kedalam matriks yang ada pada menajemen untuk keperluan perencanaan dan pengembangannya. Pendekatan manajemen sistem informasi dan teknologi informasi berdasarkan artikel yang diambil tersebut dan dikaitkan dengan contoh studi kasus pada kegiatan manajemen di perpustakaan.

\section{HASIL ANALISIS}

Sistem informasi perpustakaan SMK Negeri 3 Malang dengan menerapkan sistem otomasi perpustakaan, atau dengan kata lain kegaiatan operasional perpustakaan dilakukan dengan memanfaatkan sistem komputerisasi. Sistem yang diimplementasikan yakni dengan menggunakan aplikasi automasi perpustakaan 
dengan cara mengunduh pada situs resmi terkait aplikasi automasi tersebut. Penerapan sistem automasi di Perpustakaan SMK Negeri 3 Malang sudah didukung dengan tersedianya perangkat komputer yang tersedia yakni dengan jumlah lima unit komputer, dua diantaranya komputer untuk pustakawan dan tiga komputer untuk pengguna. Mengacu pada teori terkait tujuan perpustakaan sekolah yakni untuk memudahkan pengguna dalam penelusuran informasi, penerapan sistem automasi di perpustakaan tentu akan mendukung akan tercapainya hal tersebut. Melihat kondisi jumlah koleksi yang tersedia di Perpustakaan SMK Negeri 3 Malang dengan jumlah lebih dari 48.000 eksemplar bahan pustaka, dengan penerapan sistem sistem automasi tentu memberikan kemudahan pada pustakawan dalam melakukan pencatatan serta pengelolaan bahan pustaka.

Berdasarkan latar belakang dalam pengambilan contoh studi kasus kegaitan manajemen sistem informasi di Perpustakaan SMK Negeri 3 Malang. Penekanan pada artikel Matriks Strategis Sistem Informasi dijabarkan teknologi informasi terhadap suatu perusahaan dilihat dari dua prespektif utama. Seberapa besar ketergantungan perusahaan terhadap sistem informasi dan teknologi informasi, dan seberapa besar potensi sistem informasi dan tekbologi untuk dapat memberikan keutungan kompetitif bagi perusahaan.

Sistem informasi dapat dikategorikan berdasarkan karakteristiknya yaitu sebagai berikut:

a. Kelompok pertama adalah sistem informasi atau teknologi informasi yang hanya berfungsi sebagai penunjang perusahaan (kinerja perusahaan tidak bergantung kepada peranan teknologi informasi) dan tidak memiliki potensi yang besar dalam memberikan keunggulan kompetitif perusahaan (McFarlan menamakannya "support")

b. Jenis sistem kedua adalah teknologi informasi yang tidak secara langsung memberikan keunggulan kompetitif kepada perusahaan, namun keberadaannya mutlak diperlukan. McFarlan menamakannya "factory" (mungkin karena sifatnya yang tidak lebih sebagai mesin dalam pabrik).

c. Kelompok ketiga memperlihatkan suatu fenomena yang cukup aneh, karena yang termasuk jenis sistem ini adalah yang secara langsung dapat 
memberikan keunggulan kompetitif kepada perusahaan yang memilikinya, namun secara prinsip perusahaan tersebut tidak tergantung eksistensinya terhadap sistem informasi yang bersangkutan.

d. Kelompok terakhir adalah yang paling utama, yaitu suatu sistem informasi yang secara signifikan memiliki nilai strategis bagi perusahaan. Dan tanpa sistem ini, perusahaan yang bersangkutan dapat gulung tikar di era globalisasi informasi dewasa ini.

Perpustakaan SMK Negeri 3 Malang memanfaatkan aplikasi automasi perpustakaan, adapun dengan pemanfaataan aplikasi tersebut dapat mendukung kegiatan operasional di perpustakaan SMK Negeri 3 Malang yang meliputi kegiatan sirkulasi, penge-entry an koleksi kedalam database dan pendataan anggota perpustakaan yang digunakan untuk presensi kunjungan perpustakaan. Dikaitkan dengan kelompok yang pertama, penggunakan aplikasi tersebut diperlukan di perpustakaan. Akan tetapi, jika aplikasi tersebut tidak digunakan, kegiatan opersional di perpustakaan dapat tetap berjalan, hanya saja dengan dilakukan dengan proses manual. Sebagai contoh, kegiatan sirkulasi bahan pustaka untuk buku paket peminjaman kelas tidak dapat diproses melalui aplikasi tersebut karena tidak adanya konten yang tersedia untuk memproses peminjaman buku paket siswa dengan peminjaman selama satu semester hingga satu tahun. Adapun proses sirkulasi yang dapat diproses pada aplikasi tersebut yakni sirkulasi dengan ketentuan waktu peminjaman selama 7 hari dengan waktu perpanjangan 1 kali. Jadi peminjaman dan pengembalian terkait buku paket pegangan siswa tersebut diproses secara manual. Aplikasi tersebut juga tersedia fasilitas keanggotaan selain untuk kegiatan sirkulasi, dapat digunakan untuk presensi kunjugan perpustakaan. Hal tersebut sudah diterapkan disaat yang bersamaan dengan kegiatan PKL (praktik kerja lapangan ) yang dilakukan oleh penulis. Namun sistem presensi dengan pemanfaatan aplikasi tersebut tidak diteruskan karena pustakawan kesulitan dalam merekap atau mendata hasil kunjungan siswa ke perpustakaan yang disusun dalam laporan setiap bulannya. Jadi pustakawan menerapkan presensi kehadiran siswa ke perpustakaan dengan cara manual untuk memudahkan penyusunan laporan. 
Pemanfaataan aplikasi automasi di perpustakan SMK Negeri 3 Malang dalam kegiatan operasional perpustakaan. Selain database yang berisikan koleksi di perpustakaan SMK Negeri 3 Malang, pada aplikasi tersebut juga menyediakan fasilitas keanggotaan. Fasilitas keanggotaaan tersebut diperlukan karena untuk pembuatan KTP (Kartu Tanda Pelajar). Kartu pelajar tersebut dapat digunakan siswa untuk melakukan peminjaman dan pengembalian buku di perpustakaan dan sebagai kartu tanda siswa untuk memperoleh sarana dan fasilitas akademik yang disediakan oleh SMK Negeri 3 Malang.

Tersedianya perangkat komputer di Perpustakaan SMK Negeri 3 Malang diharapkan dapat menunjang dengan diterapkannya sistem automasi perpustakaan. Fakta dilapangan komputer yang disediakan dengan jumlah lima unit, dua untuk untuk kerja pustakawan dan tiga unit untuk pengguna yang dijabarkan satu untuk presensi, satu untuk komputer OPAC dan satu untuk fasilitas pengguna perpustakaan. Pada kegiatan oberservasi yang dilakukan di Perpustakaan SMK Negeri 3 Malang, komputer untuk presensi kehadiran tidak lagi digunakan karena pustakawan yang kesulitan untuk pendataan kehadiran pengunjung perpustakaan dalam satu bulannya. Komputer OPAC hampir tidak pernah digunakan oleh pengunjung sebagai saran untuk pencarian informasi, pengunjung yang ingin meminjam buku di perpustakaan SMK Negeri 3 Malang lebih sering bertanya langsung kepada pustakawan terkait buku yang ingin dipinjam atau dibaca ditempat, lalu pustakawan menunjukan di bagian mana buku yang dicari tersebut. Perpustakaan SMK Negeri 3 Malang menggunakan aplikasi automasi dengan mengunduh secara gratis. Seperti diketahui, aplikasi tersebut secara keseluruhan seudah sesuai untuk diterapkan di perpustakaan. Namun, setiap perpustakaan memiliki kebijakan dan ketentuan yang berbeda-beda, maka dari itu akan membuat berbagai kebijakan yang tidak dapat dijalankan dengan menggunakan aplikasi automasi tersebut. Melihat peran penting tersediannya aplikasi untuk menunjang penerapan sistem automasi di perpustakaan. Maka dari itu, perpustakaan SMK Negeri 3 Malang berencana untuk mengembangkan aplikasi automasi bekerja sama dengan library konsultant dan staff IT pihak SMK Negeri 3 Malang agar aplikasi automasi yang digunakan di perpustakaan SMK Negeri 3 
Malang dapat berjalan sesuai dengan kebijakan sekolah dan kebijakan perpustakaan SMK Negeri 3 Malang.

\section{PENUTUP}

\section{Kesimpulan}

Berdasarkan hasil analisis manajemen sistem informasi di Perpustakaan SMK Negeri 3 Malang dapat disimpulkan, manajemen sistem informasi di Perpustakaan SMK Negeri 3 Malang mamanfaatkan aplikasi automasi perpustakaan dengan lisensi freeware atau aplikasi tidak berbayar yang diunduh melalui situs resmi aplikasi tersebut. Pemanfaataan aplikasi tersebut secara keseluruhan sesuai dengan kegiatan operasional di perpustakaan. Kebijakan dari Perpustakaan SMK Negeri 3 Malang yang mengikuti kebijakan sekolah, membuat ada sebagian layanan perpustakaan tidak dapat memanfaatkan aplikasi tersebut. Dapat dikatakan jika aplikasi tersebut tidak digunakan di Perpustakaan SMK Negeri 3 Malang, layanan di perpustakaan dapat tetap berjalan dengan baik. Namun, melihat konddisi koleksi serta kebutuhan untuk pencatatan data siswa yang cukup banyak, pemanfaatan aplikasi tersebut dapat menunjang pustakawan dalam kegiatan operasional di Perpustakaan SMK Negeri 3 Malang

\section{DAFTAR RUJUKAN}

Arikunto, Suharsimi. 2010. Prosedur Penelitian: Suatu Pendekatan Praktik. Jakarta: Rineka Cipta.

Bustari, Mellina. 2015. Mengembangkan Perpustakaan Sekolah Melalui Otomasi Perpustakaan.http://download.portalgaruda.org/article.php?article =3071 $19 \&$ val $=455 \&$ title $=$ MENGEMBANGKAN\%20PERPUSTAKAAN\%20SE KOLAH\%20MELALUI\%20OTOMA SI\%20PERPUSTAKAAN. (Online). Diakses pada 31 Maret 2017

Darmono. 2001. Manajemen Dan Tata Kerja Perpustakaan Sekolah. Jakarta : Gramedia.

Indrajit, Richardus Eko. Pengantar Konsep Dasar Manajemen Sistem Informasi Dan Teknologi Informasi. http://repository.unand.ac.id /18152/1/Manaje men\%20Sistem\%20Informasi.pdf.(Online). Diakses pada 31 Maret 2017

Lasa, HS. 2009. Manajemen Perpustakaan Sekolah. Yogyakarta: Pinus Book Publisher. 
Pendit, Putu Laxman. 2009. Perpustakaan Digital: Kesinambungan \& Dinamika. Jakarta : Cita Karyakarsa Mandiri.

Undang-Undang Republik Indonesia, Nomor 43 Tahun 2007 Tentang Perpustakaan 